\title{
How much is too much
}

\section{内 藤}

博

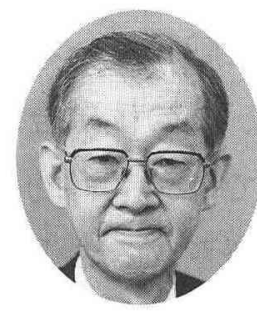

最近のわれわれ日本人のグルメぶりは恐ろしいばかりの傾向である。このままでは、 世界中のエビやマグロの殆どを食い尽くしてしまうほどの勢いである。

その一方、ついこの閒まで騒がれたコメ不足の騒動がうそのように、でんぷん型力 ロリーの日本式食生活が一応の定着を示しているのも現実のようである。

毎年の国民栄養調査が明らかに示しているように、現在の日本人の主な栄養素摂取 状況は、カルシウムを例外として、すべて基準值を満足しているか上回っていること であるが、栄養の過剰に原因する種々の成人病がじわじわと增えていることは、われ われの食生活に多くの久陥があることを如実に示している。

また、外食やコンビニエンス食の普及に伴う食事構成の単純化に原因する、リス卜 に載らない種々の微量栄養素の不足が問題となっていることも見逃せない。魚を嫌が る傾向が、ビタミン D や亜鉛の不足を引き起こすことになり、その影響は深刻なもの になるかもしれない。

このような傾向に対する一般の関心もかなり高く、健康食品の氾濫も相当なもので ある。

日本の食糧事情が不足から、やっと充足の方向に達した頃、1977年には米国人の過 剰栄養による成人病の防止策がE.ケネディー、マクバガンら当時の政界の大物を中心 とした上院特別委員会により取り上げられ、「米国人の食事目標 Dietary Goal」とし て幾つかの栄養素摂取の数值目標を明示した。

このような政策上における「栄養」の取り上げかたは画期的であり、その後の各国 の栄養・食糧政策に大きな影響を及ばすことになるが、一方ではこのような数值表現 はいろいろの波紋を及ぼす結果となった。一例として、コレスレロール摂取を 1 日 250-350mg 以下にするように锥告した結果、卵を 1 日 2 個以上食べるなということに なり、養䳕業者は大混乱に陷った。

このことは、地域、人種、食習慣などを網羅した大規模の調査研究の発展につなが ク、栄養疫学、社会医学といった学問領域が成立する端緒にもなったが、ともかく、 卵の問題はシロと判定された。

このような経験を踏まえて、米国 の USDA，NIH 合同委員会(1985) は、一歩退いた形で、数值表現を控 えた「栄養がイドライン」の形でア ドバイスすることになった。当時会

内藤 博（ないとうひろし 1928年生） 日本学術会議第 6 部会員、栄養·食糧科学研究連絡 委員会委員長、共立女子大学家政学部長、東京大学 名誉教授、農学博士

専門：農芸化学、栄養·食糧科学 
議で来日したウイスコンシン大学の A.E.ハーパー教授はこれらの経緯を表題のよう なジョークで表現したことを思い出した次第である。

ある栄養素が 1 日どのくらい必要であるかを決めるためには、いくつかの原理を適 用するが、いずれにしても多数のヒトについて、莫大な費用を伴う長期間の試験をす る必要がある。この結果をさらに年齢や環境別に分けて加重平均したものを、国民 1 人 1 日当たりの「栄養所要量」(RDA）として各国が公示しているわけであるが、個人 個人の数值でないと断っているにもかかわらず、金科玉条の数值として自分のものに してしまうのが自然の成り行きであろう。

本来栄養学は栄養素の不足を克服する目的で発展してきたので、種々のビタミン類 を始め、多くの栄養素の本態と機能が明らかにされたが、同時に最低必要量について も可成り明確に推定できるようになった。

他方、現在のような過剰栄養時代では、コレステロールやカルシウムのように、ど れだけ摂れば成人病を予防できるかという判断基準のための数值が要請されている。

特ににカルシウムについては、日本人の所要量に達しない唯一の栄養素であるのと、 骨粗鬆症、高血圧あるいは結腸がんのような主要な成人病の予防に、多量の摂取が効 果を示すという研究報告が増えていることに反映して、カルシウム剂の販売合戦が熾 烈化しているように見受けられる。

しかし、前に述べたように、「何に対して足りないか？」という一般的な疑問に対し て、カルシウムについても満足する答えを用意することができないのが現実である。 つまり、本質的に集団の平均值と個人個人の必要量との間のギャップの問題を抱之 ていることに、今更ながら痛感せざるを得ない。

現にネブラスカ大学のグループは放射性カルシウムを投与した（この研究環境だけ でも風土の大きな違いを感じるが)閉経後女性273名について詳細に吸収率を測定した 結果、大きな個人差があるうえ、米国所要量に相当する 1 日 $800 \mathrm{mg}$ のカルシウムを捸 取しても、全体の55\%は吸収率25\%以下で、有効に吸収利用できないことを示してい る。

このことからしても、ある個人が毎日の食事成分からカルシウムの摂取量を計算し て、成人のカルシウム所要量、1 日 $600 \mathrm{mg}$ にあと何 $\mathrm{mg}$ 足りないというのはナンセン スといえる。

栄養素の必要量は、個人個人の数值として明らかにすることが目標であり、それに は、各栄養素についての未解決の基礎研究もさることながら、ヒトの栄養研究に関す る広い理解と研究を進めるための組織、予算化を講じることが緊急の課題である。そ うしないと、いつまでもコーカサス系人種の体に起こっていることを日本人に当ては めるという「和魂洋才」が続けられることになろう。

学術会議としても先端的研究の推進だけではなく、このような地道でありながら、 日本の将来にふれる問題にもっと眼をむける必要があろう。 